\title{
A Study on Customer Awareness towards Pradhan Mantri Bharatiya Jnanaushadi Kendra's with Reference to Shimoga
}

\section{OPEN ACCESS}

Manuscript ID:

COM-2021-09013257

Volume: 9

Issue: 1

Month: January

Year: 2021

E-ISSN: 2582-6190

Received: 12.10 .2020

Accepted: 28.11 .2020

Published: 01.01.2021

Citation:

Manjula Bai, H. "A Study

on Customer Awareness towards Pradhan Mantri Bharatiya Jnanaushadi Kendra's with Reference to Shimoga." ComFin Research, vol. 9, no. 1, 2021, pp. 1-10.

DOI:

https://doi.org/10.34293/ commerce.v9i1.3257

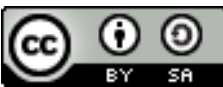

This work is licensed under a Creative Commons Attribution-ShareAlike 4.0 International License

\author{
H. Manjula Bai \\ Faculty Member, Department of Post Graduate Studies and Research in Commerce \\ Sahyadri College of Commerce and Management, Shimoga, Karnataka, India \\ https://orcid.org/0000-0002-2178-1446
}

\begin{abstract}
This paper is designed to check Customer Awareness towards Pradhan Mantri Bharatiya Jnanaushadi Kendra's. This study is finished to understand the knowledge, perception and attitude of individuals and patients towards generic medicines provided by the govt. At low cost through Jan Aushadhi Medical Stores, which supports and helps the people below the personal income. This helps to spot the problems faced by people and also helps to make your mind up and to relinquish solutions regarding the matter that, not every-one is aware of the schemes implemented by the govt. For the welfare of the people below the personal income. The successful solution is taking measures like campaigns, educating the people to form them more alert to the Jan Aushadhi Medical Store. The study target the degree of knowledge of individuals about Jan Aushadhi Medical Store, the people's awareness of Jan Aushadhi Medical schemes, to understand the willingness of individuals to shop for generic medicines, to review the understanding and people's perception on generic medicines, to study the satisfaction level of consumers towards quality, price, availability, accessibility, acceptability, affordability of those medicines and to understand about how the govt. Initiative measures reach among the people. For the study's aim, the researcher has selected 50 respondents who are aware of the PMBJPK. Descriptive research methodology is employed to conduct the study. It includes survey and fact-finding inquiries of various kinds. It focused on the issues of the advantages availed from PMBJPK. All levels of shoppers were surveyed by using a questionnaire and also, the level of satisfaction or dissatisfaction from PMBJPK was studied. Finally, the detailed information about the advantages they had received was also considered... Finally, it attempts to supply suggestions to the purchasers to teach way more about PMBJPK.

Keywords: Pradhan Mantri Bhartiya Jan Aushadhi Pariyojana Kendra (PMBJPK), Central Drug Standards Control Organisation (CDSCO), Jan Aushadhi Store (JAS), Generic Medicine, BPPI (Bureau of Pharma Public Sector Undertakings of India).
\end{abstract}

\section{Introduction}

Increased health-care expenses remain a significant concern worldwide, especially in underdeveloped and developing countries where most people are unable to satisfy them, and India isn't any exception. In step with one among the estimates, $70 \%$ of Indian people spend their $10-20 \%$ of total income as health expenses and adds up to their financial difficulties. The WHO survey performed within the year 2011 documented that $3.2 \%$ of Indians live below personal income, and lack the insurance further compounds the above situation. At the highest of the above scenario, the Indian market has several same drug formulations with different brand names. In keeping with one in all the reports, 1 lakh brand medicines are registered and fabricated from 1000 active pharmaceutical ingredients. This has resulted in thanks to mushrooming of an enormous number of pharmaceutical industries. India is ranked 3rd largest in volume and terms who brand the identical medicines by different brand names. 
This ends up in competition by adopting different marketing strategies between different pharmaceutical houses to promote their brands and further escalating the value of medicines. However, there has been an increase in the number of medicines flooding the market in their generic names to beat the price factor. However, it largely does not make an impact on economic pressure on health care as most of the branded medicines are manufactured by multinational companies and enormous Indian companies and are strongly supported by prescribing physicians. To beat this problem inflicting immense economic impact on the poor population, the Indian Government had launched the Jan Aushadhi campaign in April 2008 by opening government -controlled centers in various states to produce quality generic medicines at lower prices to their counterpart branded ones to form them easily affordable to a standard man. Currently, our country has quite 850 Pradhan Mantri Bhartiya Jan Aushadhi Kendra's functional spreading over 28 states/union territories

\section{Review of Literature}

Rohini Gupta, et al (2018), in their article "A study on the assessment of awareness on generic drugs among doctors in a tertiary care teaching hospital in north India," stated that the assessment of doctors' perceptions and understanding about generic medicines may help in recognizing the key areas which may act as a hurdle to mass-scale use of generics. The primary objective of this study was to explore the knowledge, attitude, and practice (KAP) of doctors toward generic medicines. The present study showed that a good percentage of doctors were well aware of generic medicines' usage. However, due to concerns expressed by a certain fraction of participants, further work is needed on how interventions for medical professionals and the public can lead to an increase in the awareness and acceptability of generic medicines.

Pramod Gawali, et al (2018), in their article "Study of information, attitude, and practice of prescribing generic medicines by interns, residents, and school in an exceeding lytertiary care teaching hospital Ujwala" stated that Prescription of generic drugs could reduce costs without reducing quality. Lack of information about the cost-effectiveness of generic medicines among the health-care professionals had led to a coffee rate of generic medicine prescription. In our study, we found that the prescribers had good knowledge regarding the concept of generic medicines. However, to further increase the speed of generic medicine prescription training programs on generic medicines, continuing medical educations, workshops, etc., should be organized.

Sandeep Kumar Gupta, et al (2015), in their article "A study on the knowledge, attitude, and practice of Generic Medicines among the doctors during a tertiary care teaching hospital in south India," stated that the assessment of doctor's perceptions and understanding about generic medicines may help in recognizing possible barriers to greater generic medicine usage. A good percentage of doctors knew generic medicines. They showed a good attitude about the security, efficacy and quality of generic medicines, and a majority of them said that they prescribe generic drugs. But there was a meaningful proportion who expressed concerns about generic drugs. These beliefs could represent a big hurdle to larger drug use and will cause increased health-care expenses.

Amit Dwived, et al (2015), in their article "A study on various marketing strategies used for promotion of OTC Drugs," stated that today, in the competitive market, marketing strategies play a vital role in the promotion of products and services. There are many pharmaceutical companies within the industry competing with one another. Pharmaceutical companies are changing their marketing strategies to cope up with new challenges within the business environment. For the last decade, Marketing strategies have changed significantly in the Indian pharmaceutical industry. The businesses are hugely advertising their OTC products to market them into the market. In his study, the author has tried to emphasize the importance of promoting strategies within the promotion of OTC drugs.

Anil Kalotra (2014), in their article "Marketing Strategies of various Pharmaceutical Companies," stated that Multinational pharmaceutical Companies are chargeable for this shift in marketing strategies. Leading companies are using high-end development and not adaptive development; new innovation-based 
companies are going places. Corporations not doing innovation in products and processes are finding it difficult to compete with organizations adapting innovation. My study analyses the processes and outcomes of world pharmaceutical companies. This research paper will give an insight into the provision chain management Process of those organizations and highlight the customer perception on the bottom of which organizations are framing different marketing strategies.

R.K. Srivastava and Sanjiwani Jayant Kumar (2014), in their article "Understanding of consumer's awareness about brands in the pharmaceutical industry: An empirical study," stated that the findings of the paper will help the industry for promoting the medication for the condition within which it must be taken. The results also help the pharmaceutical industry to contribute to higher health and improve the positioning. Consumers' view on a brand isn't studied to a good extent. The three components that are perception, involvement, and buying behavior, are analyzed through a scale.

Sujit S. Sansgiry, et al (2011) in their article "Consumer Perceptions Regarding drug Substitution: An Exploratory Study," stated that consumers had favorable perceptions regarding drug substitution and attitude toward generic drugs. Consumers were more favorable regarding drug substitution if they'd a favorable attitude toward generic drugs. However, some consumers still believe that drug substitution may lead to less effective medications and will compromise the standard of the medications they take. Customer' awareness of the positive aspects of drugs is vital in increasing their support for generic drug substitution practices.

Anita Kotwani (2010) researched the Pharmaceuticals Situation in India and the way Generic medicines are an inexpensive alternative to the dearer, patented, branded medicines. However, the overwhelming majority of the Indian population still has got to spend "out of pocket" on costlier, branded medicines. Various surveys in India have highlighted the problem of availability and provide cheaper generics in the Indian market. Recently, the Government of India has initiated the scheme of "Jan Aushadhi Stores," planned in each district within the country, to supply cheaper generic medicines.
However, several surveys have focused on the poor quality image of generics, both within the mindsets of prescribers, additionally as patients. This study is one in all the primary such studies, which compares the standard of 4 commonly used drugs Alprazolam, Cetirizine, Ciprofloxacin, Fluoxetine, available as generics from "Jan Aushadhi Stores", in addition to that of the respective leading brands, viz., Restyl, Alerid, Ciprobid and Fludac, from the market. These medicines were tested as per the Indian pharmacopoeial guidelines. Results indicate all the four pairs of generics vs. popular branded medicines pass the relevant pharmacopoeial tests, thereby underlining that generics are of nearly as good quality as branded medicines. The study highlights the importance of spreading awareness on the quality of generics amongst the prescribers and therefore, the public similarly.

\section{Statement of the Problem}

The problem is that not every-one is aware of the schemes implemented by the government for the welfare of the people below the poverty line. The successful solution will be taking measures like campaigns, educating the people to make them more aware of the Jan Aushadhi Medical Store.

\section{Need for the Study}

This study is done, to know the knowledge perception and attitude of people and patients towards generic medicines provided by the government at low cost through Jan Aushadhi Medical Stores supports and helps the people below the poverty line. This helps to identify the issues and problems faced by people and also helps to decide and to give a solution regarding the problem.

\section{Objectives of the Study}

- To study the degree of general knowledge of people about Jan Aushadhi Medical Store.

- To study the people's awareness of Jan Aushadhi Medical schemes.

- To know the willingness of people to buy generic medicines.

- To study understanding and people's perception of generic medicines.

- To study the satisfaction level of customers 
towards quality, price, availability, accessibility, acceptability, affordability of these medicines.

- To know about how the government initiative measures reach among the people.

\section{Scope of the Study}

The focus of this research work is to primarily study the positive impact of the Jan Aushadhi medical scheme towards people who is not affordable to buy medicine at high prices and also the people's awareness of this scheme. The study will comprise middle-class people and people Below Poverty Line

\section{Research Methodology}

The research design is a probability research design and is descriptive research.

\section{Sources of Data Collection}

Primary Data: Primary data has been used by me in the form of Questionnaire \& Observation, which are the two basic methods of collecting primary data, which suffices all research objectives.

Secondary data: Secondary data sources like the catalog of the company, product range book of the company, various internet sites, and Literature Reviews have been used.

\section{Sampling Design}

The research is designed to achieve the abovementioned objectives, and the following tools were used to collect the required data.

Sampling Method: To carry out this project, non probability sampling method is used.

Sampling Frame: The sample frame represents the groups of respondents that were contacted during the survey. It also represents the profession of the respondents that were connected for data.

Sampling Technique: To carry out this project Convenience technique has been used.

Sampling Unit: For survey, 4 generic Medicine companies have been taken.

Sample Size: The total sample size for the data collection for the research was 50 respondents.

Tools for Data Collection: Structured Questionnaires were the tools for data collection. The Questionnaire was neatly designed and constructed for the purpose in line with the objective of the study.

\section{Hypothesis}

H0: There is no substantial change in the quality of PMBJK with other competitors.

$\mathrm{H} 1$ : There is a substantial change in the quality of PMBJK with other competitors.

\section{Limitations of the Study}

- The sample size was limited to 50 customers.

- The study is restricted only to the customer level.

- Time was a big constraint.

\section{About Jan Aushadhi Store (JAS)}

Jan Aushadhi" was originally started by the UPA Government in 2008. It has been renamed and relaunched by the current Prime Minister of India, Shri Narendra Modi, in the year 2014 for the noble cause - Quality Medicines at Affordable Prices for All. The campaign was undertaken by selling generic medicines through exclusive outlets, namely "Jan Aushadhi Medical Store" in various districts of the country. In September 2015, the 'Jan Aushadhi Scheme' was revamped as 'Pradhan Mantri Jan Aushadhi Yojana' (PMJAY). In November 2016, to give further impetus to the scheme, it was again renamed "Pradhan Mantri Bhartiya Janaushadhi Pariyojana" (PMBJP).

The Jan Aushadhi initiative will make available quality drugs at affordable prices through dedicated stores selling generic medicines available at lesser prices but are equivalent in quality and efficiency as expensive branded drugs.

About Jan Aushadhi Store (JAS)

1. JAS are opened across the country.

2. The traditional working hours of JAS are $8 \mathrm{Am}$ to eight PM.

3. All therapeutic medicines are made available from Jan Aushadhi Stores.

4. Besides medicines and surgical items supplied by BPPI, Jan Aushadhi stores also sell allied medical products commonly sold in chemist shops so on improve the viability of running the Jan Aushadhi store.

5. OTC (Over-the-counter) products are often purchased by somebody without a prescription. A prescription from a registered health care provider is critical for purchasing scheduled drugs. 
6. BPPI (Bureau of Pharma Public Sector Undertakings of India) has been established under the Department of Pharmaceuticals, Govt. of India, with the support of all the CPSUs for cocoordinating procurement, supply, and marketing of generic drugs through the Jan Aushadhi Stores.

7. The quality, safety, and efficacy of medicines are ensured by getting each batch of medicines procured from CPSUs also as private suppliers tested from NABL approved laboratories and conforming to the specified standards before the identical are supplied to Super stockists /Jan Aushadhi Stores from the Warehouse of BPPI.

Jan Aushadhi Store (JAS) is opened by State Governments. Any organization / reputed NGOs / Trusts / Private Hospitals / charitable institutions / Doctors / Unemployed pharmacist/ individual entrepreneurs are eligible to use for brand new Jan Aushadhi stores. The applicants shall need to employ one B Parma / D Pharma degree holder as a Pharmacist in their proposed store.

\section{Resource Available for Jan Aushadhi Store (JAS) Store Owner}

The following financial backing is available:

NGOs / agencies / individuals establishing Jan Aushadhi stores in Government hospital premises where space is provided free from cost by Government to operating agency: BPPI will provide just the once financial assistance up to Rs. 2.50 lakh as per details given below.

- Rs.1 lakh reimbursement of furniture and fixtures.

- Rs.1 lakh way of free medicines within beginning.

- Rs. 0.50 lakh as reimbursement for computer, internet, printer, scanner, etc.

- $20 \%$ trade margin shall be included in MRP for retailers and $10 \%$ for distributors.

- Jan Aushadhi stores and Distributors are going to be allowed $2 \%$ of total sales or actual loss, whichever is lower, as compensation against the expiry of medicines. Expired goods needn't be returned to BPPI. Stocks expiring at the C\&F level will entirely be the loss of BPPI.

- Credit facilities are given to any or all Jan Aushadhi stores for 30 days against post-dated cheques. Distributors will get the credit of 60 days against post-dated cheques. C\&F agencies will deposit a security amount depending upon the business.

\section{Key Features of Pradhan Mantri Bhartiya Janaushadhi Pariyojana (PMBJP)}

1. State Governments or any organization / reputed NGOs / Trusts / Private hospitals / charitable institutions / Doctors / Unemployed pharmacist/ individual entrepreneurs are eligible to use for brand spanking new Pradhan Mantri Bhartiya Janaushadhi Kendra's.

2. The applicants shall employ one B Pharma / D Pharma degree holder as a Pharmacist in their proposed store.

3. Applications shall be submitted to BPPI, either online or offline.

4. Pradhan Mantri Bhartiya Janaushadhi Kendras are often located within Government hospital premises like private hospital premises or anywhere outside.

5. Additionally to medicines and surgical items supplied by BPPI, Pradhan Mantri Bhartiya Janaushadhi Kendra's are allowed to sell allied medical products commonly sold in chemist shops so on improve the viability of running the Pradhan Mantri Janaushadhi Kendra.

6. BPPI shall source the medicines both from Pharma PSUs further as from Private companies. However, PSUs would have the primary right to produce the products that they manufacture in their plants. BPPI shall make sure that private manufactures are only reputed organizations by incorporating strict terms and conditions within the tender specifications.

7. Tendering for medicines shall be only through e-tendering. All the tendering process shall be a completely transparent giving civil rights for all the participants.

8. BPPI shall establish a Central Ware House, C\&F agents at different locations, and Distributors all told the States/UTs.

9. On receipt of products at their central warehouse, BPPI shall draw samples and sent them to NABL accredited laboratories for inspection. Only after receiving quality certification from the inspecting laboratories, goods shall be dispatched to $\mathrm{C} \& \mathrm{~F}$ Agents and Distributors. 
10. BPPI shall plan and undertake suitable media activities to soon spread the message of generic medicines and to attain the objectives of the PMBJP.

11. Financial backing to applicants: An amount of Rs.2.5 lakhs shall be extended to NGOs/ agencies/individuals establishing Pradhan Mantri Bhartiya Janaushadhi Kendra's in Government hospital premises where space is provided freed from cost by Government to operating agency: Rs. 1 lakh reimbursement of furniture and fixtures Rs. 1 lakh by way of free medicines within the beginning Rs. 0.50 lakh as reimbursement for computer and peripherals, internet, etc. For the Pradhan Mantri Bhartiya Janaushadhi Kendras established anywhere else by private entrepreneurs / institutions / NGOs / Trusts / Charitable organizations linked with BPPI headquarters through internet shall be extended an incentive up to Rs. 2.5 lakhs. this may incline@15\% of monthly sales subject to a ceiling of Rs. 10,000/- per month up to a limit of Rs. 2.5 lakhs. In the north eastern States, i.e., Naxal affected areas and tribal areas, the speed of incentive are going to be $15 \%$ and subject to a monthly ceiling of Rs. 15,000 and a total limit of Rs. 2.5 lakhs.

12. $20 \%$ trade margin shall be included in MRP for retailers and $10 \%$ for distributors.

13. Pradhan Mantri Bhartiya Janaushadhi Kendras and Distributors will be allowed $2 \%$ of total sales or actual loss, whichever is lower, as compensation against expiry of medicines. Expired goods needn't be returned to BPPI. Stocks expiring at the C\&F level will entirely be the loss of BPPI.

14. Credit facilities are going to be given to any or all Pradhan Mantri Bhartiya Janaushadhi Kendras for 30 days against postdated cheques. Distributors will get credit of 60 days against postdated cheques. $\mathrm{C} \& \mathrm{~F}$ agencies will deposit a security amount depending upon the business.

15. BPPI shall arrange a suitable educational program for the entrepreneurs who don't have any running medicine shops.

16. Institutions / Charitable organizations / NGOs who are procuring medicines for their own consumption / free distribution to the poor and needy will be allowed to obtain medicines from BPPI CFA agents.

17. Pradhan Mantri Janaushadhi medicines will be sold through "Mobile Pradhan Mantri Janaushadhi Vans" in any case requisite approvals are obtained.

\section{Analysis and Interpretation}

Table 1: Social-Economic Profile and Opinion of Respondents

\begin{tabular}{|c|c|c|c|}
\hline $\begin{array}{l}\text { S. } \\
\text { No }\end{array}$ & Gender & $\begin{array}{c}\text { No. of } \\
\text { respondents }\end{array}$ & $\%$ \\
\hline 1 & Male & 30 & 60 \\
\hline 2 & Female & 20 & 40 \\
\hline \multicolumn{2}{|r|}{ Total } & 50 & 100 \\
\hline $\begin{array}{l}\text { S. } \\
\text { No }\end{array}$ & $\begin{array}{l}\text { Educational } \\
\text { Qualification }\end{array}$ & $\begin{array}{l}\text { No. of } \\
\text { respondents }\end{array}$ & $\%$ \\
\hline 1 & SSLC & 25 & 50 \\
\hline 2 & Graduate & 10 & 20 \\
\hline 3 & Post Graduate & 10 & 20 \\
\hline 4 & Other & 5 & 10 \\
\hline \multicolumn{2}{|r|}{ Total } & 50 & 100 \\
\hline $\begin{array}{l}\text { S. } \\
\text { No }\end{array}$ & Age group & $\begin{array}{l}\text { No. of } \\
\text { respondents }\end{array}$ & $\%$ \\
\hline 1 & Between $18-24$ & 5 & 10 \\
\hline 2 & Between 25- 34 & 7 & 14 \\
\hline 3 & Between 35- 44 & 8 & 16 \\
\hline 4 & Above 45 & 30 & 60 \\
\hline \multicolumn{2}{|r|}{ Total } & 50 & 100 \\
\hline $\begin{array}{l}\text { S. } \\
\text { No }\end{array}$ & Occupation & $\begin{array}{l}\text { No. of } \\
\text { respondents }\end{array}$ & $\%$ \\
\hline 1 & Professional & 5 & 10 \\
\hline 2 & Businessmen & 30 & 60 \\
\hline 3 & Govt. Employee & 5 & 10 \\
\hline 4 & Student & 10 & 20 \\
\hline \multicolumn{2}{|r|}{ Total } & 50 & 100 \\
\hline $\begin{array}{l}\text { S. } \\
\text { No }\end{array}$ & Income & $\begin{array}{l}\text { No. of } \\
\text { respondents }\end{array}$ & $\%$ \\
\hline 1 & Below Rs. 10000 & 5 & 10 \\
\hline 2 & Rs.11000-Rs. 20000 & 20 & 40 \\
\hline 3 & Rs.21000-Rs. 30000 & 20 & 40 \\
\hline 4 & Above Rs. 30000 & 5 & 10 \\
\hline \multicolumn{2}{|r|}{ Total } & 50 & 100 \\
\hline
\end{tabular}




\begin{tabular}{|c|c|c|c|}
\hline $\begin{array}{l}\text { S. } \\
\text { No }\end{array}$ & $\begin{array}{c}\text { Frequency of Purchase } \\
\text { of Generic Medicines }\end{array}$ & $\begin{array}{c}\text { No. of } \\
\text { respondents }\end{array}$ & $\%$ \\
\hline 1 & Occasionally & 10 & 20 \\
\hline 2 & Frequently & 30 & 60 \\
\hline 3 & Once in a year & 10 & 20 \\
\hline 4 & At the time of offer & 0 & 0 \\
\hline \multicolumn{2}{|r|}{ Total } & 50 & 100 \\
\hline $\begin{array}{l}\text { S. } \\
\text { No }\end{array}$ & $\begin{array}{l}\text { Source where they came } \\
\text { to know about PMBJK }\end{array}$ & $\begin{array}{l}\text { No. of } \\
\text { respondents }\end{array}$ & $\%$ \\
\hline 1 & Advertisement & 20 & 40 \\
\hline 2 & Word of Mouth & 20 & 40 \\
\hline 3 & Observation & 10 & 20 \\
\hline 4 & Brand image & 0 & 0 \\
\hline \multicolumn{2}{|r|}{ Total } & 50 & 100 \\
\hline $\begin{array}{l}\text { S. } \\
\text { No }\end{array}$ & $\begin{array}{c}\text { Commitment about } \\
\text { PMBJK }\end{array}$ & $\begin{array}{l}\text { No. of } \\
\text { respondents }\end{array}$ & $\%$ \\
\hline 1 & Very Committed & 10 & 20 \\
\hline 2 & Committed & 35 & 70 \\
\hline 3 & Average & 5 & 10 \\
\hline 4 & Not Committed & 0 & 0 \\
\hline \multicolumn{2}{|r|}{ Total } & 50 & 100 \\
\hline $\begin{array}{l}\text { S. } \\
\text { No }\end{array}$ & $\begin{array}{c}\text { Opinion about PMBJK } \\
\text { Stores }\end{array}$ & $\begin{array}{l}\text { No. of } \\
\text { respondents }\end{array}$ & $\%$ \\
\hline 1 & Attractive & 10 & 20 \\
\hline 2 & Boring & 0 & 0 \\
\hline 3 & Unique & 5 & 10 \\
\hline 4 & Normal & 25 & 50 \\
\hline 5 & Pleasant & 10 & 20 \\
\hline 6 & Irritating & 0 & 0 \\
\hline \multicolumn{2}{|r|}{ Total } & 50 & 100 \\
\hline $\begin{array}{l}\text { S. } \\
\text { No }\end{array}$ & $\begin{array}{l}\text { Opinion about Quality } \\
\text { in PMBJK Medicines }\end{array}$ & $\begin{array}{c}\text { No. of } \\
\text { respondents }\end{array}$ & $\%$ \\
\hline 1 & Very high quality & 12 & 24 \\
\hline 2 & Good quality & 28 & 56 \\
\hline 3 & Neutral & 10 & 20 \\
\hline 4 & Average quality & 0 & 0 \\
\hline 5 & Bad quality & 0 & 0 \\
\hline \multicolumn{2}{|r|}{ Total } & 50 & 100 \\
\hline $\begin{array}{l}\text { S. } \\
\text { No }\end{array}$ & $\begin{array}{l}\text { Opinion about Price in } \\
\text { PMBJK Medicines }\end{array}$ & $\begin{array}{c}\text { No. of } \\
\text { respondents }\end{array}$ & $\%$ \\
\hline 1 & Fairly priced & 20 & 40 \\
\hline 2 & Over priced products & 0 & 0 \\
\hline 3 & Under priced & 30 & 60 \\
\hline \multicolumn{2}{|r|}{ Total } & 50 & 100 \\
\hline
\end{tabular}

\begin{tabular}{|c|l|c|c|}
\hline $\begin{array}{c}\text { S. } \\
\text { No }\end{array}$ & $\begin{array}{c}\text { Opinion about the } \\
\text { Government to come } \\
\text { up with More Initiative } \\
\text { Measures }\end{array}$ & $\begin{array}{c}\text { No. of } \\
\text { respondents }\end{array}$ & $\%$ \\
\hline 1 & Strongly Agree & 10 & 20 \\
\hline 2 & Agree & 30 & 60 \\
\hline 3 & Neutral & 10 & 20 \\
\hline 4 & Disagree & 0 & 0 \\
\hline 5 & Strongly Disagree & 0 & 0 \\
\hline & Total & 50 & 100 \\
\hline
\end{tabular}

Source: Survey data

The above table analysis the social, economic profile and opinion of the respondents who avail the benefits of PMBJK. Out of 50 respondents, $60 \%$ of males and $20 \%$ are females who avail the benefits of PMBJK.

Among them, $50 \% \%$ have studied up to SSLC and are Businessmen, their monthly income being 10000-30000 p.m.

The means of awareness is through friends and relatives, i.e., word of mouth and advertisements,

$60 \%$ of the respondent's visit these stores frequently and $70 \%$ of them are committed,

$50 \%$ of the respondents say that the store atmosphere is Normal.

$56 \%$ of the respondents are happy with the quality of the medicines; they say that it is of good quality.

$60 \%$ of the respondents say that the price of the medicines is under-priced.

Overall, respondents are satisfied with the PMBJK and they suggest many more initiatives from the Government.

\section{Hypothesis Testing using Chi-Square Test Hypothesis}

H0: There is no substantial change in the quality of PMBJK with other competitors.

$\mathrm{H} 1$ : There is a substantial change in the quality of PMBJK with other competitors. 


\begin{tabular}{|c|c|c|c|c|c|}
\hline Quality of Medicines in PMBJK & \multirow{2}{*}{ Very High } & High & Medium & Low & Total \\
\cline { 1 - 5 } With Competitors & 2 & 17 & 4 & 0 & 23 \\
\hline Cipla & 1 & 11 & 1 & 2 & 15 \\
\hline Man force & 2 & 3 & 1 & 1 & 7 \\
\hline Ranbaxy & 1 & 3 & 0 & 1 & 5 \\
\hline Others & 6 & 34 & 6 & 4 & 50 \\
\hline Total & & &
\end{tabular}

Chi square $=(\mathrm{O}-\mathrm{E})^{2} / \mathrm{E}$

$\mathrm{O}=$ Observed frequency; $\mathrm{E}=$ Expected frequency;

DOF - Degrees of freedom $=(\mathrm{R}-1)(\mathrm{C}-1)=(4-1)(4-1)=9$

Expected frequency $=($ Row total $\times$ Column Total $) /$ Grand Total

\begin{tabular}{|c|c|c|c|c|c|}
\hline S. No & Observed & Expected & O-E & $(\mathbf{O}-\mathbf{E})^{2}$ & $(\mathbf{O}-\mathbf{E})^{2} / \mathbf{E}$ \\
\hline 1 & 2 & 2.76 & -0.76 & 0.5776 & 0.209275 \\
\hline 2 & 1 & 1.8 & -0.8 & 0.64 & 0.355556 \\
\hline 3 & 2 & 0.84 & 1.16 & 1.3456 & 1.601905 \\
\hline 4 & 1 & 0.6 & 0.4 & 0.16 & 0.266667 \\
\hline 5 & 17 & 15.64 & 1.36 & 1.8496 & 0.118261 \\
\hline 6 & 11 & 10.2 & 0.8 & 0.64 & 0.062745 \\
\hline 7 & 3 & 4.76 & -1.76 & 3.0976 & 0.650756 \\
\hline 8 & 3 & 3.4 & -0.4 & 0.16 & 0.047059 \\
\hline 9 & 4 & 2.76 & 1.24 & 1.5376 & 0.557101 \\
\hline 10 & 1 & 1.8 & -0.8 & 0.64 & 0.355556 \\
\hline 11 & 1 & 0.84 & 0.16 & 0.0256 & 0.030476 \\
\hline 12 & 0 & 0.6 & -0.6 & 0.36 & 0.6 \\
\hline 13 & 0 & 1.84 & -1.84 & 3.3856 & 1.84 \\
\hline 14 & 2 & 1.2 & 0.8 & 0.64 & 0.533333 \\
\hline 15 & 1 & 0.56 & 0.44 & 0.1936 & 0.345714 \\
\hline 16 & 1 & 0.4 & 0.6 & 0.36 & 0.9 \\
\hline & & Total & & 8.474404 \\
\hline
\end{tabular}

\section{Inference}

Calculated Value $=8.48$

Degree of freedom $=9$

Table value of chi-square for 9 degrees of freedom@5\% level of significance is 16.919

Since the calculated value is less than the table value, the Null hypothesis is accepted, so the alternative hypothesis is rejected. Hence proved that there is no substantial change in the quality of Medicines of PMBJK with other competitors.

\section{Findings of the Study}

1. Out of 50 respondents, $60 \%$ of males and $20 \%$ are females who avail the benefits of PMBJK.
2. Among them, $50 \% \%$ have studied up to SSLC and are Businessmen, their monthly income being 10000-30000 p.m.

3. The means of awareness is through friends and relatives, i.e. word of mouth and advertisements,

4. $60 \%$ of the respondents visit these stores frequently, and $70 \%$ of them are committed,

5. $50 \%$ of the respondents say that the store atmosphere is Normal.

6. $56 \%$ of the respondents are happy with the quality of the medicines; they say that it is of good quality.

7. $60 \%$ of the respondents say that the price of the medicines is underpriced. 
8. Overall, respondents are satisfied with the PMBJK, and they suggest many more initiatives from the Government.

\section{Suggestions for the Study}

- Pradhan Mantri Bhartiya Jan AushadhiYojanaa is one of the foremost useful scheme offered to poor and bourgeoisie people by Central Government but presently Pradhan Mantri Bhartiya Jan Aushadhi Yojana scheme not achieved the goal evidently from Central Government.

- Apart from the survey we can see that the majority of the respondents belong to rural they aren't privy to the scheme so government should regularly put an advertisement on mass media.

- Hoarding should be placed on Public Area like stop, Bazaar, main circles in Shivamogga

- Pradhan Mantri Bhartiya Jan Aushadhi Yojana Pamphlet should be circulated to each primary Healthcare centers

- Government should promote Pradhan Mantri Bhartiya Jan Aushadhi Yojana scheme through TV Advertisement

\section{Conclusion}

The Government of India breathed life into the Jan Aushadhi Programme, 2008, and plans to run it on a Campaign Mission Mode. The Jan Aushadhi Campaign could be a self-sustaining business model re-launched in March by the Department of Pharmaceuticals under the Pradhan Mantri Jan Aushadhi Scheme. Supported the principle of Not for Profits but with Minimal Profits, this program has been re-launched with the target of ensuring the availability of quality medicines at affordable prices to all or any. The Pharmaceutical Industry in India has developed a powerful capability to supply quality branded and generic medicines in most of the therapeutic categories. It has within the past three decades evolved from a 1500 crore industry in 1980 to a $1,19,000$ crore industry in 2012 . Unfortunately, though most of those medicines are priced reasonably as compared to other countries, the poor in India are still unable to afford the branded ones. the govt of India had stepped in to assist the poor through regulations like control of Scheduled and NonScheduled Drugs, Uniform VAT, and Reduction in
Excise duty. To further alleviate the condition of the poor and help them attain a better quality of life through access to quality medicines, the govt has now launched the Jan Aushadhi Campaign.

The key challenge within the scheme is going to be implementation and execution with the charge that the tip customer doesn't finally end up with fake or spurious drugs. However, there's little question about the very fact that this scheme should be implemented on a war footing so the rich and therefore the poor alike are ready to avail of quality healthcare for a stronger life.

The goal of providing Universal health care can only be achieved; if the availability of quality medicines at the right price is ensured. Doctors in India mostly prescribe branded drugs. A serious legal revamp is required so that Doctors arena guided by the incentives they receive from pharmaceutical companies. It'd be a serious push to JAS if Doctors start prescribing generic drugs.

\section{References}

Ashwini, and Niveditha Sanil. "A Study on Jan Aushadhi Shops of Udupi District." Asia Pacific Journal of Research, vol. 1, 2020, pp. 87-92.

Dwivedi, Amit, and Gaurav Lodha. "A Study on Various Marketing Strategies used for Promotion of OTC Drugs." Research Hub: International Multidisciplinary Research Journal, vol. 2, no. 2, 2015, pp. 1-4.

Gawali, Ujwala Pramod, et al. "Study of Knowledge, Attitude, and Practice of Prescribing Generic Medicines by Interns, Residents, and Faculty in a Tertiary Care Teaching Hospital Ujwala." National Journal of Physiology, Pharmacy and Pharmacology, vol. 8, no. 12, 2018, pp. 1631-1634.

Gupta, Rohini, et al. "A Study on Assessment of Awareness on Generic Drugs among Doctors in a Tertiary Care Teaching Hospital in North India." International Journal of Research in Medical Sciences, vol. 6, no. 4, 2018, pp. 1362-1367.

Gupta, Sandeep Kumar, et al. "A Study on the Knowledge, Attitude, and Practice of Generic Medicines among the Doctors in a Tertiary 
Care Teaching Hospital in South India." National Journal of Physiology, Pharmacy \& Pharmacology, vol. 5, no. 1, 2015, pp. 39-44. Kalotra, Anil. "Marketing Strategies of Different Pharmaceutical Companies." Journal of Drug Delivery \& Therapeutics, vol. 4, no. 2, 2014, pp. 64-71.

Nagarajappa, Maruthi Haluvarthy, and Srinivasan Srivatsa. "Modelling Customers' Buying Behaviour of Jan Aushadhi (Generic Medicines)." Indian Journal of Pharmaceutical Education and Research, vol. 54, no. 1, 2020, pp. 175-186.

Pradhan Mantri Gram Sadak Yojana, http://omms. nic.in

Preethi, R., and Daya. K. Benny. "A Study on Customer Awareness and Preferences towards Hypermarkets with Special Reference to Big
Bazaar, Palakkad." IJARIIE, vol. 1, no. 4, 2016, pp. 323-330.

Sansgiry, Sujit S., et al. "Consumer Perceptions Regarding Generic Drug Substitution: An Exploratory Study." Journal of Pharmaceutical Marketing \& Management, vol. 17, no. 1, 2005, pp. 77-91.

Solomon, Milton, and C. Sundar. "Impact of Brand Awareness and Customer Satisfaction Towards Services of Jan Aushadhi Medicalstores." International Journal of Recent Technology and Engineering, vol. 8, 2019, pp. 546-551.

Srivastava, R.K., and Sanjiwani Jayant Kumar. "Understanding of Consumer's Awareness about Brands in Pharmaceutical Industry: An Empirical Study." Journal of Medical Marketing, vol. 14, no. 2-3, 2014, pp. 99-107.

\section{Author Details}

H. Manjula Bai, Faculty Member, Department of Post Graduate Studies and Research in Commerce,

Sahyadri College of Commerce and Management, Shimoga, Karnataka, India,

EmailID: manjularaikar76@gmail.com. 